\title{
Water Pollution and Leukemia: A Model for Interdisciplinary Research in the Classroom Experiences Incorporating Effective Pedagogical Approaches for Community College General Biology I Lab Students
}

\author{
$\mathrm{Na} \mathrm{Xu}^{1}$, Holly Porter-Morgan ${ }^{1}$, Nathan Doran ${ }^{1} \&$ Charles Keller ${ }^{1}$ \\ ${ }^{1}$ Department of Natural Sciences, LaGuardia Community College, City University of New York, USA \\ Correspondence: Charles Keller, Department of Natural Sciences, LaGuardia Community College, City University \\ of New York, USA.
}

Received: August 25, 2016

Accepted: September 24, 2016

Online Published: October 12, 2016

doi:10.5430/ijhe.v5n4p122

URL: http://dx.doi.org/10.5430/ijhe.v5n4p122

\begin{abstract}
STEM (Science, Technology, Engineering, and Mathematics) education in the United States faces a host of problems including low recruitment and retention in STEM disciplines, under-representation of multiple segments of the US population, and a host of other issues. These problems are well recognized and a variety of solutions are being implemented by interested parties at multiple points along the STEM education pipeline. Incorporating research into STEM classes is an effective way of enhancing student success in STEM education at the undergraduate level. This paper describes the development and implementation of a research-based laboratory module for community college General Biology I lab students that addresses potential relationships between water pollution and cancer while simultaneously implementing established High Impact Practices. This work is part of a larger effort to recruit and retain the next generation of Earth and Environmental Systems engineering students at the undergraduate level. Our inherently interdisciplinary model, which integrates multiple pedagogical elements, can be adapted for implementation in a wide variety of undergraduate STEM courses. This laboratory module allows students to benefit from authentic research, while gaining skills in gathering scientific data, making connections with global and personal issues, and illustrating relevant discipline concepts.
\end{abstract}

Keywords: Research in the classroom, Pedagogy, Biology, Cancer, Environmental engineering, Integrative learning, Global Learning

\section{Introduction}

STEM (Science, Technology, Engineering, and Mathematics) education in the United States currently faces a wide variety of well-documented challenges including poor recruitment and retention rates in degree-granting STEM programs (Graham et al., 2013), low participation of underrepresented groups, high attrition rates and a host of other problems (discussed in Palmer \& Wood, 2013). The challenges facing STEM education in the United States may translate into existential problems for the nation in general. Without a qualified, diverse, scientific workforce and a multitude of innovative thinkers, the United States cannot hope to maintain its position as a world leader in innovation and discovery. The intimate relationship between scientific advance and modern global economics also suggests that a failure to recruit and nurture the next generation of STEM professionals may contribute to stagnation or regression of the American economy in the long term with a possible resulting decrease in the quality of life for all Americans (Neumark, Johnson, \& Mejia, 2013). Given the interconnectedness of the modern global economy, stagnation or regression in any country may radiate out into the world at large. In addition to these larger concerns are millions of individual stories of wasted time and effort, crushing student loan debt, and lost opportunities. The problems facing American STEM education are complex and will necessitate addressing deep-seated socio economic and cultural issues to fully address the challenges facing STEM education in the US (Bastedo, 2016). However, the solutions to such issues may take generations to manifest. In the meantime, educators, policy makers, and other interested parties must focus on more tangible battles such as simply getting more students to enroll in, and successfully complete, degree-granting programs in STEM fields.

While there are a wide variety of programs and strategies designed to improve recruitment and retention in degree-granting STEM programs, the incorporation of real research experiences into the STEM curriculum appears to be a particularly effective way of enhancing STEM student success in terms of retention and degree completion (as 
suggested by the work of Brownell \& Swaner, 2010; Eagen et al., 2010; Mervis, 2016 and others). Though traditional laboratory teaching exercises may effectively illustrate important concepts, they may fail to spark the genuine passion for discovery that forms the bedrock of perseverance and success in science education and indeed science itself. Exposing undergraduates to the experience of pursuing the unknown allows educators to share the excitement of discovery and provides students with a more tangible grasp of the true nature and relevance of scientific endeavors.

This manuscript describes the development and implementation of a research-based laboratory module for community college biology students. It is part of a larger effort to improve recruitment and retention in an Earth and Atmospheric Systems Engineering (ESE) program. Given the severe environmental concerns facing the entire world, the education and training of engineers and other STEM professionals who will address environmental issues is of significance to everyone alive today, as well as future generations. The work described here is designed to enhance student interest and success in STEM courses of relevance to environmental issues (specifically, General Biology I, in this case). It also provides fellow educators with a useful model for implement authentic research into laboratory classrooms that can be adopted for educational use in multiple STEM discipline lab classes including environmental science, chemistry, biology, and environmental engineering. This project was designed to build on the established benefits of research in the classroom experiences while incorporating other high impact practices.

The Continuous Intensive Learning Environment in STEM (CILES) initiative is a U.S. Department of Education funded partnership between faculty at two community colleges and one four-year college within a larger urban college system designed to enhance recruitment and retention in the Earth and Atmospheric Systems Engineering (ESE) program. The CILES program seeks to support students in their crucial first and second year of STEM education (Watkins \& Mazur, 2013) while providing a seamless transition from community college to a four-year college where students will complete their bachelor's degree in ESE. Within the CILES framework, ESE students have the opportunity to complete most of their basic science classes including physics, chemistry, biology, and calculus at the community college level where they benefit from small class size, paid research opportunities with faculty mentors, relatively low tuition, and tutoring support. A transfer articulation agreement between the participating community colleges and the senior college ensures that all credits earned at the community college level transfer as equivalent credit to the four-year college. As part of the larger CILES initiative, we set out to design and implement a laboratory module for General Biology I lab students which would incorporate genuine scientific research, illustrate fundamental biological concepts already included in the course, address matters of interest to ESE students, and be generalizable for use across campuses in both biology and environmental science or engineering classes.

Our General Biology I course is the first of a two semester biology sequence and is required for all students majoring in biology, environmental science, environmental engineering and related programs. At our institution, the two semester general biology sequence introduces the fundamental concepts that are required for understanding the nature of living things. Concepts covered in the first half of the sequence include evolution, genetics, photosynthesis, cellular structure and metabolism, biotechnology, animal development and the scientific method, while the second semester covers comparative anatomy, ecology, how living things are classified, and several other fundamental topics. The course includes a lecture component and a laboratory component that complements the lecture portion and reinforces fundamental concepts via hands-on activities and experiments.

The General Biology I curriculum incorporates several topics that coincide with ongoing faculty research. While faculty research programs at our institution involve undergraduate students, they are conducted independently of our courses and are not part of the curriculum. Several of our faculty members investigate the ecological effects of various contaminants, including trace metals, nutrients, and fecal indicator bacteria, at a severely polluted urban waterway immediately adjacent to our campus. Other faculty at our institution study leukemia using Drosophila melanogaster (fruit flies) as a model system. The General Biology I curriculum includes a discussion of cancer, but does not examine potential links between pollution and cancer. This provides us the perfect opportunity to incorporate faculty research into the existing General Biology I curriculum by designing a laboratory module that addresses the possible relationships between water contaminants and cancer. This module allows students to participate in real research while simultaneously placing cancer into a larger environmental context.

Cancer is a scourge that, despite decades of intense research, remains a major cause of human death and suffering worldwide. According to the World Health Organization (WHO) 2012 data, 8.2 million people died because of cancer and 14 million new cases were reported globally in 2012 (Stewart \& Wild, 2016). The WHO also estimates a 70\% global increase in cancer incidence over the next two decades. At the most fundamental level, cancer can be thought of as cell division run amok. Our General Biology I curriculum discusses cell division and its regulation in detail. The course discusses cancer in this context but connections to the larger societal effects of cancer and the relationship 
between cancer and environmental pollution are not touched upon in any detail. Faculty research programs addressing various aspects of cancer are common and our institution is no exception, although there is no formal connection between those research efforts and course content.

Fruit flies are commonly used in many undergraduate general biology lab exercises to illustrate a variety of concepts (e.g. genetics). This fact allowed us to easily integrate elements of ongoing faculty Leukemia research into our General Biology I lab curriculum. Such integration would effectively illustrate concepts specific to the class while also taking advantage of the known benefits conferred on students by research in the classroom experiences. A specific strain of fruit flies carrying a mutation in a gene known to influence Leukemia incidence and progression in humans represented a convenient system with which to develop cancer-related classroom activities for General Biology I lab students. The laboratory module involved growing mutant, tumor-prone fruit flies on food made from sterile or heavily polluted water and counting the easily visible tumors that might result. This particular strain of mutant fruit flies exhibits easily observable tumors at a low incidence under normal conditions and we hypothesized that exposure to heavily polluted water would increase tumor incidence and size as indicated by a tumor index which can be easily assessed by simple student observation. Interested readers will find a more detailed description of the fruit fly system used and experimental procedures in appendix 1.

Possible causal relationships between water pollution and cancer remain unclear though correlational evidence exists from a variety of sources (see Vartiainen et al., 1993; Cohn et al., 1994; Szyguła, Bunio, Tubek, 2011 for examples). Water pollution is a pervasive global concern as all countries deal with the ongoing environmental consequences of industrialization (see Ebenstein, 2012, Hoekstra \& Wiedmann, 2014, Whitmee et al., 2015 for discussion). Indeed, as many as 2.5 billion human beings may not have reliable access to fresh water (Gleick \& Ajami, 2014). While water pollution is a global issue, we wanted to help our students see local connections in the context of cancer as well. As mentioned previously, our campus has the dubious distinction of being located immediately adjacent to the heavily polluted Newtown Creek urban waterway allowing easy access to polluted water samples obtained by faculty studying ecology and remediation at the site in question.

Until the advent of contemporary environmental regulations, Newtown Creek was essentially a sewer for a variety of industrial effluent including petrochemical byproducts, heavy metals, and other industrial contaminants (see Klein et al., 1974; Block \& Bernard, 1988; Hurley, 1994; Campbell, 2007 for discussion). We felt that the convenient location, relevance to student lives, relevance to faculty research interests, and ecological significance of the site in relation to public health concerns, made a study of potential relationships between water pollution and cancer an ideal model for an undergraduate research in the classroom experience. The resulting laboratory module thus allowed students to visualize the connections between the basic biological topic of cell-cycle regulation, and the issues of cancer and water pollution, which are important societal concerns at both the local and global level.

\section{Materials and Methods}

\subsection{Participants}

We implemented this work in two sections of our General Biology I lab class. Each section initially included twenty-four students though several dropped the course prior to completing the project. Different faculty taught each section though assignments and assessments were the same across sections. An experienced undergraduate student researcher who had been involved in the ongoing faculty Leukemia research served as a peer mentor, assisting students with laboratory procedures. The peer mentor was not a student in the class.

General Biology I student majors include biology, environmental science, environmental engineering, and liberal arts math and science. Liberal arts math and science majors are typically science students who have not chosen a specific major or who are seeking to enter our highly competitive allied health programs. Prerequisites for the course are limited to general English and mathematics courses. Many students take General Biology I as their first college-level science course. While this laboratory module was supported by a larger effort related to environmental engineering students, the major is relatively new and this cohort did not contain any environmental engineering students. As General Biology I is a required course for environmental engineering students, part of our goal was to incorporate issues of relevance to environmental engineering students into our General Biology I curriculum. It should be noted that environmental engineering students are only now being given the option of taking General Biology I at the community college level, however, expect more environmental engineering students in the future. Demographically, our student body reflects the diversity of our urban location. According to 2014 data generated by the college's office of Institutional Research, $60 \%$ of our total student population were born in a country other than the US with over 106 native languages self-identified. Demographically, $43 \%$ of our students self-identify as non-white Hispanic while $21 \%$ 
identify as Black, $21 \%$ as Asian, $14 \%$ as White and $1 \%$ self-identify as "Other." $57 \%$ of our students are women. The majority of our students come from low-income households.

\subsection{Incorporation of Other Effective Pedagogical Practices}

2.2.1 High impact practice: Integrative Learning. In addition to implementing the established benefits of research in the classroom experiences, we also sought to include other pedagogical tools into our laboratory module. In response to guidance provided by the American Association of Colleges and Universities (a national accreditation body which oversees most colleges in the United States), our institution is currently in the process of implementing a series of high impact practices institution-wide as new, interdisciplinary core competencies and abilities which we hope to instill in our students by the time they graduate. Among these core competencies is Integrative Learning. As a competency, Integrative Learning involves making connections between concepts learned in one class/discipline and other, perhaps seemingly unrelated areas of study while linking these ideas to student's personal experience outside of the classroom. A useful discussion of Integrative Learning can be found in Miller's 2005 article as well as many other sources (Miller, 2005) including an example related to engineering students presented by Singer and colleagues (Singer, Foutz, Navarro, \& Thompson, 2015). The laboratory module presented in this paper meets the criteria for this competency because it connects fundamental biological concepts to environmental issues of direct relevance to students' own communities and the world at large and is is inherently interdisciplinary. However, Integrative Learning goes beyond simple interdisciplinary relationships. This design also incorporates prompts requiring students to relate the laboratory module to their own lives, reflect upon their experience, and visually document circumstances in their own life that illustrate relevance to the module described in this work. The specifics of these prompts are included in the lab report design presented below.

2.2.2 High impact practice: Global Learning. In addition to the Integrative Learning core competency discussed in the previous paragraph, our institution is also in the process of adopting Global Learning as a core competency we hope to instill in our students. The institutional framing language related to the Global Learning core competency reads as follows: "Global Learning offers students meaningful opportunities to analyze and explore complex global challenges, communicate respectfully in diverse environments, and apply learning to take responsible, ethical action in contemporary global contexts. Global Learning is based on the principle that the world is comprised of interdependent yet inequitable systems. Further, it acknowledges that higher education has a vital role in expanding knowledge of human and environmental systems, addressing privilege and stratification, and guiding change and sustainable development. Global Learning also fosters the ability to advance equity and justice locally and globally. It is acquired cumulatively across students' entire college career, as well as through curricular and co-curricular experiences." A research in the classroom experience integrating actual experimental research related to fundamental class concepts while placing them in the context of larger global issues such as water pollution and its relationship to cancer would represent an ideal embodiment of the global competency we seek to instill in our students. We did not explicitly assess Global Learning outcomes though they were implicit in our design.

2.2.3 High impact practice: Peer mentorship. The incorporation of peer mentorship models into undergraduate research experiences is an effective way of enhancing educational outcomes (Lopatto, 2010). We included peer mentorship in the module by having an undergraduate student involved with faculty research attend our lab sessions and talk about his own experience with undergraduate research while also guiding students through experimental procedures. The peer mentor was not a student in the class, but instead was a participant in the ongoing faculty research on which this laboratory module was based on.

\subsection{Background Presentation}

A background presentation, discussion, and assignment of relevant readings preceded the hands on research activities in the laboratory module. These activities were designed to give students a brief introduction to the specifics of the fly cancer model system, the waterway in question, and the possible relationships between water pollution and cancer. Two articles deemed accessible to General Biology I lab students were assigned as outside reading. One article describes putative relationships between water pollution and cancer in the state of New Jersey (Cohn et al., 1994), while the other is a report prepared by a local non-profit organization (Weiss \& Heimbinder, 2010), which discusses the history of the waterway in question and related issues from a lay perspective, including interviews with community members. The second reading was included to deepen student understanding of the waterway's relevance to the community. 


\section{Lab Report Format Guidelines}

SCB201 Lab

\section{Following all of these guidelines will be crucial to get full points for this lab report.}

1. Lab report for Leukemia Research with Drosophila melanogaster:

\section{a. Introduction Section (20pts):}

- Define Leukemia

- Referring to the research papers provided on blackboard, introduce the background of water pollution and leukemia development. Do not use any article from non-scholarly resources.

- Introduce Newtown Creek.

- Introduce the Hopscotch ${ }^{\text {Tumorous-Lethal }}$ flies used in our study. What kind of protein does the Hopscotch gene encode? What kind of mutations do Hopscotch $^{\text {Tumorous-Lethal }}$ flies carry? Why does it lead to Leukemia?

- Describe the goal of the research.

b. Hypothesis (5points): What is the hypothesis tested by our experiment?

c. Materials and Methods (10 pts): Include material, equipment and procedures for our experiments

\section{d. $\quad$ Results section (25 pts):}

- Describe what happened to the parent flies at $29^{\circ} \mathrm{C}$ and room temperature (refer to the data provided by N. Doran... posted on blackboard).

- How did you measure the tumor size and calculate tumor index? Calculate the tumor Index and summarize your results in the below table format (use the data your group collected on June $6^{\text {th }}$ If you were absent, you will have to ask your classmates to share the data they acquired):

\begin{tabular}{|l|l|l|}
\hline & Tumor Index & Number of flies counted \\
\hline $\begin{array}{l}\text { Hopscotch } \\
\text { in purified water food (normal } \\
\text { control) }\end{array}$ & & \\
\hline $\begin{array}{l}\text { Hopscotch } \\
\text { in polluted water food (dirty } \\
\text { water) }\end{array}$ & & \\
\hline
\end{tabular}

e. Conclusion and Discussion (15 pts): Based on your observations and tumor index counting, reach a conclusion about what impact the polluted water may have on flies and leukemia formation.

Discuss the importance of using animal models like Drosophila to study human diseases.

format:

f. References (5 points): Cite your selected publication using APA or MLA

https://owl.english.purdue.edu/owl/resource/560/01/

https://owl.english.purdue.edu/owl/resource/747/01/ 
g. Reflection (20 pts): Write 3-5 paragraphs of reflection (minimum 500 words) answering the below questions:

- Before this class, have you ever conducted any scientific

research?

- How do you like this cancer research conducted in the lab

class?

- Did you experience any challenges or difficulties during this

research?

- How may this research help you develop more understanding about cancer and environmental risks existing in our daily life?

research?

- How may this experience help you understand cancer

module?

- How would you evaluate the peer mentor for this laboratory

- Relate this experience to your daily life. If you were a cancer research scientist, what other environmental risks might you be interested in exploring using Hopscotch ${ }^{\text {Tumorous-Lethal }}$ flies? Referring to what we did in the lab, please write a short (one paragraph) proposal to explain how you would test your idea.

- (5pts) Please take a picture of something you encounter in your life/neighborhood etc... that is relevant to the topics addressed during this research. Please post your image on a photo sharing service (Instagram, snapchat, etc...) along with some keywords describing the relevance of your image to cancer. Please paste the link here. Now, please upload your lab report to the "assessment" tab found in the class ePortfolio (not your own) next to your name.

Note: In general, you should be able to communicate clearly, efficiently and accurately with others (in this case, me) using lab reports, so that other scientists can repeat your experiments based on your reports without any bias and question. No personal feeling should be expressed in the lab report.

Your groupmates may share the same data and conclusion with you, but you have to write your own lab report without copying each other. Your independent analysis and thinking should be reflected in data analysis, results interpretation and discussions.

Academic integrity will be strictly applied. The Safeassign on blackboard function will be used to compare your work with others and the open resources. Over $40 \%$ similarity will be considered cheating.

Figure 1. Lab report assignment

\subsection{Student Survey}

Following completion of all aspects of the, a brief student survey was administered in order to assess student perceptions regarding the impact of the laboratory module on their learning. The survey was administered by someone other than their instructor and was completely anonymous with no identifying items. Survey items not requiring yes or no responses were assessed on a simple 0-3 scale as follows: $0=$ strongly disagree, $1=$ disagree, $2=$ agree, $3=$ strongly agree. Several students chose not to participate in the survey or were not present at the time of survey administration resulting in the submission of twenty-four completed surveys.

\subsection{Assessment of Integrative Learning}

In addition to grading student research reports based on the itemized point value included in the assignment prompt, we also analyzed student reflections for evidence of Integrative Learning using our institution's integrative learning rubric (Figure 2). We analyzed reflections from twenty student reports chosen at random from the two General Biology I lab sections in which the assignment was utilized. It should be noted that the Integrative Learning rubric is not course 
specific, but instead is applied by faculty in diverse disciplines across the institution. It is not a grading rubric, but rather it is designed to assess average student progress over the course of a two-year education at our institution. Multiple courses in the curriculum have been designated for assessment of integrative learning at early, middle, and late points as students progress towards graduation. For purposes of institution-wide assessment, student work is analyzed using the rubric below and one holistic score is generated. For example, a student assignment might be given a "3" or " 4 " based on summative consideration of all four rubric dimensions. For our purposes, we chose to score each dimension independently. It is possible for a student to receive a high grade on an assignment but not display integrative learning proficiency. This is particularly true in the case of our lab reports as the prompts designed to explicitly elicit students to apply Integrative Learning represented a small percentage of total possible points for the assignment.

\begin{tabular}{|c|c|c|c|c|}
\hline Dimension & Proficient - 4 & Competent - 3 & Developing - 2 & Novice - 1 \\
\hline $\begin{array}{l}\text { Connections } \\
\text { Between \& Among } \\
\text { Academic } \\
\text { Disciplines } \\
\text { Identifies and draws } \\
\text { insight from } \\
\text { connections across } \\
\text { disciplinary } \\
\text { perspectives, } \\
\text { knowledge and skills }\end{array}$ & $\begin{array}{l}\text { Synthesizes and/or } \\
\text { draws conclusions by } \\
\text { connecting examples, } \\
\text { facts, and/or theories } \\
\text { from more than one field } \\
\text { of study or perspective. }\end{array}$ & $\begin{array}{l}\text { Connects \& compares } \\
\text { examples, facts, and/or } \\
\text { theories from more than } \\
\text { one field of study or } \\
\text { perspective. Begins to } \\
\text { draw conclusions. }\end{array}$ & $\begin{array}{l}\text { Connects } \\
\text { examples, facts, } \\
\text { and/or theories } \\
\text { from more than } \\
\text { one field of study } \\
\text { or perspective. }\end{array}$ & $\begin{array}{l}\text { Presents } \\
\text { examples, facts, } \\
\text { and/or theories } \\
\text { from one or more } \\
\text { fields of study or } \\
\text { perspective. }\end{array}$ \\
\hline $\begin{array}{l}\text { Connections to } \\
\text { Experience } \\
\text { Identifies and draws } \\
\text { insight from } \\
\text { connections across } \\
\text { relevant learning } \\
\text { experiences, } \\
\text { including personal, } \\
\text { co-curricular, and } \\
\text { academic }\end{array}$ & $\begin{array}{l}\text { Synthesizes connections } \\
\text { among multiple learning } \\
\text { experiences inside and } \\
\text { outside of classroom to } \\
\text { deepen understanding } \\
\text { and broaden point of } \\
\text { view. }\end{array}$ & $\begin{array}{l}\text { Connects examples of } \\
\text { personal or cocurricular } \\
\text { learning to academic } \\
\text { knowledge to deepen } \\
\text { understanding. }\end{array}$ & $\begin{array}{l}\text { Compares } \\
\text { relationships } \\
\text { between personal } \\
\text { or cocurricular } \\
\text { experiences and } \\
\text { academic } \\
\text { knowledge to } \\
\text { infer similarities } \\
\text { or differences. }\end{array}$ & $\begin{array}{l}\text { Identifies } \\
\text { relationships } \\
\text { between personal } \\
\text { or cocurricular } \\
\text { experiences and } \\
\text { academic content } \\
\text { or knowledge. }\end{array}$ \\
\hline $\begin{array}{l}\text { Ability to Apply } \\
\text { Learning across } \\
\text { Diverse Contexts } \\
\text { Applies knowledge, } \\
\text { skills, abilities, } \\
\text { theories \&/ or } \\
\text { methodologies across } \\
\text { different learning } \\
\text { experiences (inside or } \\
\text { outside the } \\
\text { classroom) }\end{array}$ & $\begin{array}{l}\text { Applies skills, } \\
\text { knowledge, theories, } \\
\text { and/or methodologies } \\
\text { from one learning } \\
\text { experience to another to } \\
\text { offer solutions to a } \\
\text { problem or issue. }\end{array}$ & $\begin{array}{l}\text { Applies skills, } \\
\text { knowledge, theories, } \\
\text { and/or methodologies } \\
\text { from one learning } \\
\text { experience to another to } \\
\text { explain problem or issue. }\end{array}$ & $\begin{array}{l}\text { Applies skills, } \\
\text { knowledge, } \\
\text { theories, and/or } \\
\text { methodologies } \\
\text { from one learning } \\
\text { experience to } \\
\text { another to explore } \\
\text { a problem or } \\
\text { issues }\end{array}$ & $\begin{array}{l}\text { Applies skills, } \\
\text { knowledge, } \\
\text { theories, and/or } \\
\text { methodologies } \\
\text { from one learning } \\
\text { experience to } \\
\text { another. }\end{array}$ \\
\hline
\end{tabular}




\section{Reflection \& Self-Assessment}

Demonstrates a developing sense of self as a learner, building on prior experiences to respond to new and challenging contexts
Critically evaluates strengths and challenges; connects current sense of self to past \&/ or future selves across multiple \&/ or diverse contexts.
Consistently demonstrates ability to reflect on experiences and/or examine personal identity as a learner.

Describes and evaluates strengths and challenges. Begins to describe self over time \&/or in different contexts.

Demonstrates ability to reflect on experiences and/or examine personal identity as a learner.
Describes
strengths and challenges within a specific learning context.
Demonstrates emergent ability to reflect on experiences and/or examine personal identity as a learner.
Describes strengths and challenges in a general learning context.

Demonstrates
limited or no
ability to reflect
on experiences
and/or examine
personal identity
as a learner.

Figure 2. Integrative Learning assessment rubric. Adopted from American Association of Colleges and Universities value rubrics

\section{Results}

Our discussion in this context focuses on the educational aspects of the laboratory module, while the full details of the larger cancer and water pollution research project will be presented in a separate publication.

\subsection{Experimental Results}

The tumor-prone flies used in the laboratory module display tumors at permissive temperatures with lethality manifesting as temperature increases. The initial experimental design involved growing flies at $29^{\circ} \mathrm{C}$ consistent with documented permissive temperatures for this strain. However, we observed significant lethality in all conditions at this temperature requiring us to set up the experiment a second time using lower cultivation temperatures $\left(25^{\circ} \mathrm{C}\right)$. Even at room temperature, flies grown on media including contaminated water rarely survived to generate offspring and few offspring were available for student scoring. Students were able to score the tumor index of flies grown on media using the sterile water control condition, however. These experimental data did not allow us to accept or reject our initial hypothesis that exposure to Newtown Creek water would increase tumor rates though collection and analysis of these data still represented a useful learning experience for students.

\subsection{Lab Report Results}

As mentioned previously, we analyzed the student lab reports in two ways. On average, students did quite well on their lab reports in terms of grades though the non-graded rubric measures of Integrative Learning were less impressive as shown in Table 1. Students scored in the "novice" to "developing" range in terms of making connections between and among academic disciplines and making connections to experience. On average, students scored in the "novice" to "competent" range in terms of applying learning across diverse contexts and reflection/self-assessment. It should be noted that we don't necessarily expect students at this early point in their education to consistently display proficiency in any of these dimensions.

Table 1. Lab report outcomes

\begin{tabular}{|c|c|}
\hline Dimension & Average score \\
\hline Lab report grade & $\begin{array}{l}92.3 \% \text { (not including students who did no } \\
\text { assignment) }\end{array}$ \\
\hline Connections Between \& Among Academic Disciplines & 1.6/4 (standard deviation $+/-.66, \mathrm{n}=20)$ \\
\hline Connections to Experience & $1.9 / 4($ standard deviation $+/-1.25, \mathrm{n}=20)$ \\
\hline Ability to Apply Learning across Diverse Contexts & $2.4 / 4($ standard deviation $+/-.72, \mathrm{n}=20)$ \\
\hline Reflection \& Self-Assessment & $2.7 / 4($ standard deviation $+/-1.48, \mathrm{n}=20)$ \\
\hline
\end{tabular}

3.2.1 Student reflections and images. The inclusion of reflective writing prompts in the formal lab report led students to consider the impact of their learning experience and relate what they had learned to their own life in keeping with Integrative Learning practice. Students were also asked to formulate their own questions based on the results of the laboratory module in the hopes of indoctrinating students with the "what comes next?" way of thinking that is crucial for success in science. Select examples of student reflections written in response to lab report prompts can be found in 
appendix two. In addition to written reflections, students were asked to take digital photographs that demonstrated relationships between the topics addressed in this module and their own lives. The combination of this imagery and the accompanying captions allowed students to make connections between pollution, cancer, and their lives in ways that extended beyond their written lab reports. The resultant images are not shown in order to maintain confidentiality though they are described and student captions are included. Asking students to document relevant situations in their own lives further enhances the relationship between class exercises and the student's own life experience in keeping with the practice of Integrative Learning. Examples can be found in appendix 2.

\subsection{Survey Results}

Our survey results revealed that most students had not conducted authenticresearch in any of their prior classes and would like to have the opportunity to participate in research in their future classes. Responses to other survey items were marked as "agree" or above on average, with the most positive responses relating to the helpfulness of the peer mentor and increased interest in research as a result of participation in the laboratory module. Our survey results also demonstatedthat the research experience improved students learning and their interest in biological or environmental science research. Additionally, most students would like to participate in a similar research in the future. Survey results are summarized Table 2 .

Table 2. Student survey responses

\section{$\underline{\text { Survey item }}$}

Before this class, have you ever conducted any scientific research?

Would you like to participate in a similar project in another science class?

The goal of the research was easy to understand.

The research procedure was easy to understand.

The results of the research were easy to analyze and understand.

I received valuable help from the instructor while conducting the research.

I gained new skills in scientific research.

I received a better understanding of cancer and related environmental risks.

I became more interested in biological, environmental science, or cancer research because of this laboratory module.

The peer mentor was helpful

\section{Student response $(\mathrm{n}=24)$}

$\mathrm{No}=86 \%$, Yes $=14 \%$

$\mathrm{No}=21 \%$, Yes $=79 \%$

2.3/3 (standard deviation $+/-.27$ )

$2.2 / 3$ (standard deviation $+/-.22$ )

$2 / 3$ (standard deviation $+/-.37$ )

2.2/3 (standard deviation +/-.47)

2.3/3 (standard deviation +/-.19)

2.3/3 (standard deviation +/-.31)

$2.4 / 3$ (standard deviation $+/-.23$ )

2.4/3 (standard deviation +/-.4)

\section{Discussion}

The model presented in this work effectively enhanced student understanding of basic General Biology I concepts such as cell-cycle regulation and cancer while simultaneously placing them in the larger context of environmental pollution. While the value of research in the classroom experiences for STEM students is already well established, our laboratory module integrated elements of other high impact practices including integrative learning, Global Learning, and peer mentorship. As mentioned in the introduction, part of our goal was to develop a lab module that would be of relevance to environmental engineering students while simultaneously illustrating fundamental class concepts relevant to all biology students and incorporating high impact practices. We also developed the lab module such that it is adaptable for use in courses other than General Biology I. We feel that we have accomplished these goals. With slight changes in content emphasis, reading selection, or experimental specifics, this laboratory module can be adopted for use in advanced environmental engineering, environmental science, introductory chemistry, or other related courses. Overall, we contend that the lab module described here presents a useful model for the implementation of research in the classroom pedagogy, which integrates additional high impact practices and can be easily adopted across disciplines. 
In this circumstance, experimental "failure" as observed in our first attempt to run the experiment may actually have been a useful learning experience. Ellis and colleagues discuss how the usefulness of failure as a learning experience is contingent on how the failure is evaluated (Ellis, Mendel, \& Nir, 2006). In our case, students were explicitly asked to consider why our first experiment may have failed and what might have gone wrong. This sort of thinking is consistent with the daily experience of many STEM professionals, particularly in the experimental sciences. Student reflections suggest that this came as a surprise. Many science students, particularly those in the early stages of their education, see science as the collection of facts leading to absolute, black and white answers to pressing problems. Hypotheses are formed, carefully tested, then accepted or rejected. Case closed and on to the next question! This incomplete view of science may actually be reinforced by traditional educational laboratory exercises where the "right" answer is known and students who fail to achieve the expected result "must have done something wrong." Oftentimes, a STEM professional can do everything correctly and still be confused by what they discover requiring them to rethink their approach and perhaps abandon ideas altogether. The laboratory module presented here exposed students to the fact that authentic scientific research often results in new questions rather than concrete answers. Scientists are pushing the boundaries of what is known and often face failures that they may not fully understand. We feel that this experimental "failure" translated into educational success in this context.

The inclusion of a peer mentor into the implementation of the module was well received by students. As a research assistant on a faculty led project, the peer mentor presented our cohort with an example of how students just like themselves can be involved in real research, even at the community college level. In addition to guiding student lab procedures, the peer mentor took a few minutes to discuss his own educational experiences and describe how he became involved in faculty research at our institution. This may have been the most valuable aspect of our peer mentor's role in the laboratory module. Many students were unaware that opportunities to be involved in research existed at the community college level. Survey and reflection responses suggest that students appreciated someone just like themselves talking about research rather than professors who may often seem like some elevated "other." These perceptions can be particularly pervasive among student bodies predominantly consisting of economically challenged students such as ours (Curtis, Drummond, Halsey, \& Lawson, 2012).

Did we succeed in our attempts to incorporate integrative learning and Global Learning practice? The results are mixed. We analyzed student reflections in order to assess integrative learning using the general rubric in use at our institution. This analysis was somewhat confounded by the fact that many students were obviously saying what they wanted us to hear with little apparent thought or analysis ("I enjoyed this project very much and it made me much more interested in cancer and water pollution"). The design of our assessments explicitly incorporated several aspects of integrative learning practice though others could have been implemented more effectively and higher point values probably would have elicited more effort on the part of some students. Students generally failed to make explicit connections between the laboratory module and their other coursework/learning though some implied it. It should be noted that the prompts included in our lab report assignment could have asked students to explore connections to other courses more explicitly. In terms of self-reflection and relation of laboratory module content to personal experience, many students did this quite well with many discussing how the module made them think about possible cancer risks they may be encountering in their daily lives. Seven students mentioned that they had lived near Newtown Creek at some point. Of these seven, none of them ever knew anything about the heavily polluted nature of the waterway in their neighborhood. Many students discussed people they know who had been impacted by cancer. Despite the apparently low average scores, it should again be noted that the rubric we used is not a grading rubric but a general rubric used in many classes at our institution in order to see how well, on average, students at various points in their education exhibit integrative learning skills. We do not expect necessarily expect high rubric scores for students in General Biology I, as they tend to be at the early stages of their college education. We believe that the design of the laboratory module itself implemented Integrative Learning practice, In terms of the Global Learning high impact practices, the worldwide importance of cancer and water pollution were implicitly incorporated into our project. While we designed the project to be of relevance to personal, local, and global issues, we did not implicitly build prompts into our assessments designed to evoke Global Learning thinking among our students nor did we explicitly assess Global Learning. In the future, we would like to make Global Learning practice a more explicit part of our model but it was not a major focus of this implementation other than the inherent global relevance of the topics addressed.

While we acknowledge the relatively small sample size and largely qualitative nature of our results, we believe that the laboratory module presented here successfully merges several effective pedagogical strategies and can serve as a model for fellow educators to utilize in a variety of classes. The effectiveness of research in the classroom experiences is well documented in the literature and this module further builds upon such findings by incorporating peer mentorship, Integrative Learning practice and elements of Global Learning practice. We are unable to comment at this 
time on the potential improved student retention resulting from our project, as this work is ongoing. In the future, we would like to follow this cohort of students to assess how their retention and graduation rates compare to General BIology I lab students from sections not participating in this laboratory module. We will complement the work presented here by creating a lab module for introductory chemistry lab students involves designing experiments to test the water for a variety of contaminants in order to determine why the contaminated water reduces fly life span and inhibits their embryonic development.

Other possible applications of our general model using tumor-prone flies in educational contexts include studying the effects of UV radiation, air pollution, food additives, or any other potential cancer causing agents of interest. Students suggested several ideas during the laboratory sessions, including testing benzene, radiation, food cooked in microwaves, and air pollution. Such research-based laboratory modules can be used as effective teaching tools in a variety of classes while simultaneously generating real scientific data at minimal expense. In addition, this work illustrates that research data produced in the classroom can serve as complementary data for ongoing faculty research projects outside of class. This leads, in turn, to future faculty publications, research-based laboratory modules, and research in the classroom projects. We look forward to seeing how other educators may build upon and improve the model presented in this work.

\section{Acknowledgements}

This research was funded by the Department of Education "The Alliance for Continuous Learning Environments in STEM (CILES)" HIS - Title-V grant \# P031C110158

\section{References}

Bastedo, M. N. (2016). American Higher Education in the Twenty-First Century: Social, Political, and Economic Challenges. JHU Press.

Binari, R., \& Perrimon, N. (1994). Stripe-specific regulation of pair-rule genes by hopscotch, a putative Jak family tyrosine kinase in Drosophila. Genes \& development, 8(3), 300-312. http://dx.doi.org/10.1101/gad.8.3.300

Block, A. A., \& Bernard, T. J. (1988). Crime in the waste oil industry. Deviant behavior, 9(2), 113-129. http://dx.doi.org/10.1080/01639625.1988.9967774.

Brownell, J. E., \& Swaner, L. E. (2010). Five high-impact educational practices: Research on learning outcomes, completion and quality. Washington, DC: American Association of Colleges and Universities.

Campbell, L. K. (2007). New York City's Forgotten Industrial Waterway: Assessment, Goals, and Indicators for Long-Term Sustainability of the Newtown Creek. United Nations 15th Commission on Sustainability.

Cohn, P., Klotz, J., Bove, F., Berkowitz, M., \& Fagliano, J. (1994). Drinking Water Contamination and the Incidence of Leukemia and Non-Hodgkin's Lymphoma. Environmental health perspectives, 102(6-7), 556. http://dx.doi.org/10.1289/ehp.94102556

Curtis, D. D., Drummond, A., Halsey, J., \& Lawson, M. J. (2012). Peer-Mentoring of Students in Rural and Low-Socioeconomic Status Schools: Increasing Aspirations for Higher Education. National Centre for Vocational Education Research Ltd. PO Box 8288, Stational Arcade, Adelaide, SA 5000, Australia.

Eagan, M. K., Hurtado, S., Chang, M. J., Garcia, G. A., Herrera, F. A., \& Garibay, J. C. (2013). Making a difference in science education: The impact of undergraduate research programs. American Education Research Journal, 50, 683-713. http://dx.doi.org/10.3102/0002831213482038

Ebenstein, A. (2012). The consequences of industrialization: evidence from water pollution and digestive cancers in China. Review of Economics and Statistics, 94(1), 186-201. http://dx.doi.org/10.1162/REST_a_00150

Ellis, S., Mendel, R., \& Nir, M. (2006). Learning from successful and failed experience: the moderating role of kind of after-event review. Journal of Applied Psychology, 91(3), 669. http://dx.doi.org/10.1037/0021-9010.91.3.669.

Gleick, P. H., \& Ajami, N. (2014). The world's water volume 8: The biennial report on freshwater resources (Vol. 8). Island press.

Graham, M. J., Frederick, J., Byars-Winston, A., Hunter, A. B., \& Handelsman, J. (2013). Increasing persistence of college students in STEM. Science, 341(6153), 1455-1456. http://dx.doi.org/10.1126/science.1240487

Hoekstra, A. Y., \& Wiedmann, T. O. (2014). Humanity's unsustainable environmental footprint. Science, 344(6188), 1114-1117 http://dx.doi.org/10.1126/science.1248365 
Hurley, A. (1994). Creating Ecological Wastelands:" Oil Pollution in New York City, 1870-1900". Journal of Urban History, 20(3), 340. http://dx.doi.org/10.1177/009614429402000303

Jones, A. V., Kreil, S., Zoi, K., Waghorn, K., Curtis, C., Zhang, L., ... \& White, H. (2005). Widespread occurrence of the JAK2 V617F mutation in chronic myeloproliferative disorders. Blood, 106(6), 2162-2168. http://dx.doi.org/10.1182/blood-2005-03-1320

Klein, L. A., Lang, M., Nash, N., \& Kirschner, S. L. (1974). Sources of metals in New York City wastewater. Journal (Water Pollution Control Federation), 2653-2662.

Li, W. X. (2008). Canonical and non-canonical JAK-STAT signaling. Trends in cell biology, 18(11), 545-551. http://dx.doi.org/10.1016/j.tcb.2008.08.008

Lopatto, D. (2010). Undergraduate research as a high-impact student experience. Peer Review, 12(2), 27.

Luo, H., Hanratty, W. P., \& Dearolf, C. R. (1995). An amino acid substitution in the Drosophila hopTum-l Jak kinase causes leukemia-like hematopoietic defects. The EMBO Journal, 14(7), 1412.

Miller, R. (2005). Integrative Learning and assessment. Peer Review, 7(4), 11.

Myrick, K. V., \& Dearolf, C. R. (2000). Hyperactivation of the Drosophila Hop Jak kinase causes the preferential overexpression of eIF1A transcripts in larval blood cells. Gene, 244(1), 119-125. http://dx.doi.org/10.1016/S0378-1119(99)00568-5

Neumark, D., Johnson, H., \& Mejia, M. C. (2013). Future skill shortages in the US economy? Economics of Education Review, 32, 151-167. http://dx.doi.org/10.1016/j.econedurev.2012.09.004

Mervis, J. (2016). Genuine research keeps students in science. Science, 352(6291), 1266-1266. http://dx.doi.org 10.1126/science.352.6291.1266

Palmer, R. T., \& Wood, J. L. (2013). Community colleges and STEM: Examining underrepresented racial and ethnic minorities. Routledge.

Singer, K. P., Foutz, T., Navarro, M., \& Thompson, S. (2015). Investigating the Extent That an Integrative Learning Module Broadens the Perception of First-Year Students about the Engineering Profession. American Journal of Engineering Education, 6(2), 99-111. http://dx.doi.org/10.19030/ajee.v6i2.9505

Szyguła, R., Bunio, A., \& Tubek, S. (2011). The Content of Elements in Rainwater and Its Relation to the Frequency of Hospitalization for Chronic Lymphocytic Leukemia and Chronic Myeloid Leukemia in Opole Voivodship, Poland, During 2000-2002. Biological trace element research, 141(1-3), 41-52. http://dx.doi.org/10.1007/s12011-010-8717-y

Vartiainen, T., Pukkala, E., Rienoja, T., Strandman, T., \& Kaksonen, K. (1993). Population exposure to tri-and tetrachloroethene and cancer risk: Two cases of drinking water pollution. Chemosphere, 27(7), 1171-1181. http://dx.doi.org/10.1016/0045-6535(93)90165-2

Shi, S., Larson, K., Guo, D., Lim, S. J., Dutta, P., Yan, S. J., \& Li, W. X. (2008). Drosophila STAT is required for directly maintaining HP1 localization and heterochromatin stability. Nature cell biology, 10(4), 489-496. http://dx.doi.org/10.1016/0045-6535(93)90165-2

Siegel, R. L., Miller, K. D., \& Jemal, A. (2016). Cancer statistics, 2016. CA: a cancer journal for clinicians, 66(1), 7-30. http://dx.doi.org/10.3322/caac.21332

Stewart, B., \& Wild, C. P. (2016). World cancer report 2014. World.

Watkins, J., \& Mazur, E. (2013). Retaining students in science, technology, engineering, and mathematics (STEM) majors. Journal of College Science Teaching, 42(5), 36-41.

Weiss, R., \& Heimbinder, M. (2010) Newtown Creek Community Health \& Harms Narrative Project (CHHNP): Final Report from the Newtown Creek Alliance.

Whitmee, S., Haines, A., Beyrer, C., Boltz, F., Capon, A. G., de Souza Dias, B. F., ... \& Horton, R. (2015). Safeguarding human health in the Anthropocene epoch: report of The Rockefeller Foundation-Lancet

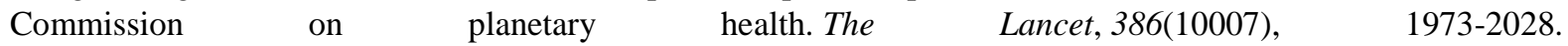
http://dx.doi.org/10.1016/S0140-6736(15)60901-1 